\title{
How useful and reliable are disaster databases in the context of climate and global change? A comparative case study analysis in Peru
}

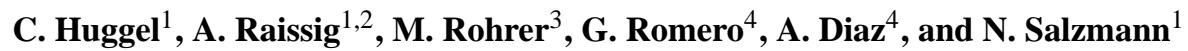 \\ ${ }^{1}$ Department of Geography, University of Zurich, 8057 Zurich, Switzerland \\ ${ }^{2}$ Geotest AG, 3052 Zollikofen, Switzerland \\ ${ }^{3}$ Meteodat, 8005 Zurich, Switzerland \\ ${ }^{4}$ PREDES - Centro de Estudios y Prevención de Desastres, San Isidro, Lima, Peru \\ Correspondence to: C. Huggel (christian.huggel@geo.uzh.ch)
}

Received: 23 December 2013 - Published in Nat. Hazards Earth Syst. Sci. Discuss.: 17 June 2014

Revised: 5 February 2015 - Accepted: 18 February 2015 - Published: 9 March 2015

\begin{abstract}
Damage caused by weather- and climate-related disasters have increased over the past decades, and growing exposure and wealth have been identified as main drivers of this increase. Disaster databases are a primary tool for the analysis of disaster characteristics and trends at global or national scales, and they support disaster risk reduction and climate change adaptation. However, the quality, consistency and completeness of different disaster databases are highly variable. Even though such variation critically influences the outcome of any study, comparative analyses of different databases are still rare to date. Furthermore, there is an unequal geographic distribution of current disaster trend studies, with developing countries being underrepresented.

Here, we analyze three different disaster databases in the developing-country context of Peru: a global database (Emergency Events Database: EM-DAT), a multinational Latin American database (DesInventar) and a national database (Peruvian National Information System for the Prevention of Disasters: SINPAD). The analysis is performed across three dimensions: (1) spatial scales, from local to regional (provincial) and national scale; (2) timescales, from single events to decadal trends; and (3) disaster categories and metrics, including the number of single disaster event occurrence, or people killed and affected.

Results show limited changes in disaster occurrence in the Cusco and Apurímac regions in southern Peru over the past four decades but strong positive trends in people affected at the national scale. We furthermore found large variations of the disaster metrics studied over different spatial and tempo-
\end{abstract}

ral scales, depending on the disaster database analyzed. We conclude and recommend that the type, method and source of documentation should be carefully evaluated for any analysis of disaster databases; reporting criteria should be improved and documentation efforts strengthened.

\section{Introduction}

Economic losses due to weather- and climate-related disasters have increased over the past decades (Barthel and Neumayer, 2012; IPCC, 2012). Between 1980 and 2007 a total of about 1.42 million people were killed and over USD 900 billion in financial loss were observed globally (WMO, 2013). In the context of climate change there is concern that economic and other type of damage and loss will further increase in the future (IPCC, 2012; ISDR, 2009). Within the United Nations Framework Convention on Climate Change (UNFCCC), a working program on loss and damage has been initiated and supported during the international climate negotiations of the past few years. The UNFCCC and the main international policy framework for disaster risk reduction, the Hyogo Framework for Action, call on data and information on disaster events to effectively develop policies and actions to manage and reduce risks. Databases are a primary source and tool to store and manage a range of data on disasters.

Among the most known disaster databases with global coverage, the Emergency Events Database (EM-DAT), main- 
tained by the World Health Organization (WHO) Collaborating Center for Research on Epidemiology of Disasters (CRED), is publicly available and has been used in several scientific studies (Barredo, 2009; Peduzzi et al., 2009; Peduzzi and Herold, 2005). NatCatSERVICE (Munich Re, 2014), from the reinsurance company Munich Re, is the largest database but is not open access. SwissRe's Sigma (Swiss Re, 2014) is another major disaster database and likewise not open access.

In the context of global climate change, researchers have increasingly started to analyze changes in the occurrence of disaster events and related fatalities and economic damage and loss. It should also be noted that disasters are the result of the physical impact of a climatic event, and the exposure and vulnerability of the system affected (Cutter et al., 2008; Cutter and Finch, 2008; Huggel et al., 2013; Wisner et al., 2004). So far, growing exposure of people and assets, and increasing wealth, have been identified as the main drivers of change in financial disaster losses (Bouwer, 2011; IPCC, 2012). Many studies have thus focused on a global scale or on a few selected developed countries (Barredo, 2010; Neumayer and Barthel, 2011; Pielke Jr. et al., 2008; Schmidt et al., 2010).

While the identification of the main drivers of increasing financial losses represents a robust result of global relevance, there are still several issues that have been addressed scarcely or not at all. First, there is an unequal geographic distribution of high-quality databases and related analyses (Gall et al., 2009). Studies on changes of disaster events and different types of losses are much rarer in developing countries than in developed countries, such as in Europe or the United States. This is of particular concern because developing countries typically have a higher vulnerability to weather- and climaterelated extreme events (Adger et al., 2003; Füssel, 2010). Furthermore, there is even less information available at subnational scales in developing countries. To some degree, this deficiency is related to the availability and quality of disaster databases in those countries.

Second, and directly related to the aforementioned statement, there is insufficient research comparing different disaster databases and analyzing related implications (Gall et al., 2009). The form and methods of how data and information are observed, reported, collected and stored in the databases critically influence the outcome of any analysis (Kron et al., 2012). There exists no international consensus concerning the way in which disaster data are compiled (CRED, 2013). Consistency in data collection throughout time is an additional issue that is of major importance for trend analysis; nonetheless it is often very difficult to track and check it. Developing countries often face greater institutional instability, and thus consistency over time is of particular concern, as responsible institutions or personnel change more often. This is corroborated by a recent comparative review of country-level and multinational disaster databases by the United Nations Development Programme (UNDP). This study found, for in- stance, that more than $50 \%$ of the databases analyzed contain gaps with no entries for specific years, and only $17 \%$ of the databases have applied a quality control procedure (UNDP, 2013). These shortcomings are particularly important in view of the role databases play, or are foreseen to play, for disaster risk reduction policies and actions.

Here, we address the aforementioned limitations by (1) exploring the use of disaster databases for analyzing spatiotemporal changes in the occurrence of weather- and climaterelated disasters at subnational scales in a developing country context in the Andes of Peru, and by (2) carrying out a straightforward comparative analysis of two or more databases for the same periods and spatial scales (national and subnational). For this purpose, we use a global (EMDAT), a multinational Latin American (DesInventar) and a national database (Peruvian National Information System for the Prevention of Disasters: SINPAD) for Peru.

Not all disaster databases follow clear criteria as to what type of events to include. This is also related to inconsistent or missing definition of the term "disaster", and some databases, such as SINPAD or DesInventar, also include many events that may not be considered a disaster by many standards, because the damage is limited. We nevertheless maintain here the term "disaster" because the introduction of criteria for the purpose of this study would lack a basis in the data sources. The spatial scales involved in our analysis are mainly at the subnational and national scale, while the timescales include decadal-scale analysis as well as single disasters. We specifically investigate the value of different disaster databases for the heavy-rainfall and flood disasters in early 2010 in Cusco, Peru, and put this disaster in the associated climatic context. Although we try to shed some light on the underlying causes of the observed disaster patterns at the national scale, such an analysis is not a primary focus of this paper, mainly due to limited availability of corresponding data, in particular on the subnational scale.

The paper is structured as follows: we first introduce the study regions; the disaster and climatic data used, along with a definition of extreme events considered; and the methods applied. We then present the results of the spatiotemporal analysis of disaster changes over the past four decades at the subnational scale of the "regiones" of Cusco and Apurímac, followed by a short analysis of the national-scale comparison of different databases. Finally we analyze the disaster database entries and climatic conditions of the 2010 Cusco floods.

\section{Study region}

A main focus of this study lies on two administrative regions in southern Peru, Cusco and Apurímac (Fig. 1). Peru distinguishes between the administrative spatial units of "regiones", "provincias" and "distritos", where regiones include provincias, and provincias include distritos. To avoid any 


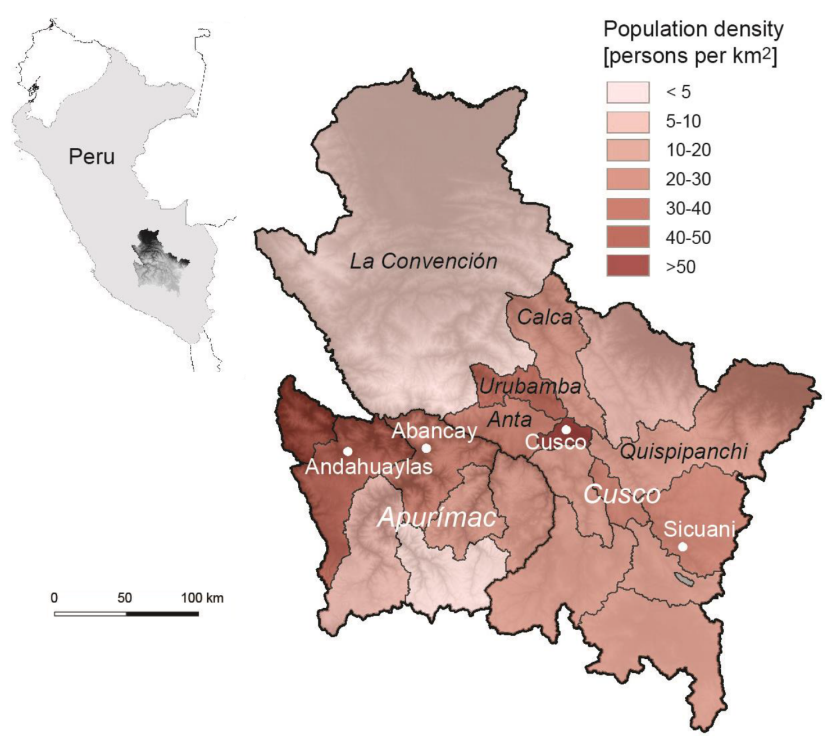

Figure 1. Map of study area with the two regiones Apurímac and Cusco. Important cities are indicated in white; provincias in the region of Cusco strongly affected by the 2010 disaster are indicated in black. Population density is given at the level of provincias. Administrative boundaries of the regiones appear in bold black lines, while those of the provincias appear in light black lines.

confusion with English terms, we will use here the original Peruvian terms in Spanish. Cusco and Apurímac extend over an area of 72000 and $21000 \mathrm{~km}^{2}$, respectively, from elevations of less than 300 to over $6300 \mathrm{~m}$ a.s.l. A great share of the area is high Andean territory with elevations of $2500 \mathrm{~m}$ a.s.l. and above. Glacierized mountain ranges exist in the west and the center of the study region. The topographic, ecologic and climatologic diversity is high in the region. Vegetation and climate zones include warm and humid tropical lowland areas in northern Cusco, both warm-arid and warmhumid zones with extensive forests in medium elevations up to ca. $2500 \mathrm{~m}$ a.s.l., followed by a zone up to $3500 \mathrm{~m}$ a.s.l. that is cultivated with a variety of crops. The climate in this zone has distinct seasons: a dry winter and a wet summer. Frequent frosts occur above $3500 \mathrm{~m}$ a.s.l., but several crops are still cultivated. Grassland dominates the zone between 4000 and $4800 \mathrm{~m}$ a.s.l., while above $4800 \mathrm{~m}$ a.s.l. glaciers and perennial snow occur. In the Altiplano areas from about 3800 to $4800 \mathrm{~m}$ a.s.l., local people keep livestock such as cameloids (lamas, alpacas, vicuñas), sheep and cattle and to some extent cultivate potatoes, quinoa, barley and other crops (Tapia, 1997). Many small population centers in the high Andes are isolated, with poor infrastructure and educational, social and health services, and subsistence farming dominates. The Altiplano area is characterized by high interannual climate variability, with climatic extremes posing notorious threats to the highly vulnerable population.

Larger urban centers exist at lower elevations of 2500 to $3500 \mathrm{~m}$ a.s.l., including the regional capital Cusco with about
0.5 million inhabitants. The population of the whole study region is 1.65 million. The main traffic and other infrastructure extends along a northwest-southeast corridor.

\section{Data and methods}

Disaster data used in this study are based on three disaster databases, from global to multinational and national level.

$E M-D A T$ is a global disaster database, and it is maintained by CRED, Université Catholique de Louvain, Belgium. EM-DAT is based on data from organizations of the United Nations, non-governmental organizations, insurance companies, scientific institutions and media (CRED, 2013). EM-DAT distinguishes between two generic categories of disasters (natural and technological), followed by several subgroups including geophysical, meteorological, hydrological, climatological and biological disasters. Each of those subgroups is again divided into a number of disaster types (e.g., floods, landslides, avalanches, etc.). For each disaster reported, information is provided as regards the date; people killed, injured, made homeless or affected; and estimated damage (in USD) if available. At least one of the following criteria needs to be fulfilled to report a disaster in EM-DAT: (1) 10 or more people reported killed, (2) 100 or more people affected, (3) declaration of a state of emergency or (4) call for international assistance.

DesInventar is a multinational-scale database and inventory system for a wide range of disasters, their characteristics and impacts (DesInventar, 2013). It includes information at the local, to national and multinational level. It has its origin in the mid-1990s when information on small- to mediumscale disasters was not available for the Andes region, nor for the rest of Latin America. A group of scientists and experts from several institutions therefore formed the Network of Social Studies in the Prevention of Disasters in Latin America (La RED) and developed the concepts and methods for a disaster database relying on existing newspaper, government and other reports, for nine countries in Latin America, including the Andean countries. More recently, DesInventar has been expanded to some selected countries in Africa and Asia. In the case of Peru, DesInventar stores information on disaster events since 1970, exclusively based on reports in the Peruvian national newspaper El Comercio. This newspaper is Lima based, and therefore a certain local bias in documentation is reflected, with a relatively higher number of events reported from the capital region if compared to the regiones.

The national-scale disaster database used here is SINPAD of the National Institute of Civil Defense (INDECI). SIN$P A D$ consists of inventories of events since 2001 at the level of regiones, provincias and distritos, and it reports data about number of fatalities and people affected, infrastructure damage, surface area affected, etc. (INDECI, 2013). SINPAD includes weather- and climate-related disasters as well as geo- 
logical ones such as related to volcanic eruptions and earthquakes.

Population data for the study region were retrieved from the Peruvian National Institute of Statistics and Informatics (INEI). The 2007 and earlier census provides demographic, economic and social data on the level of the administrative units of Peru. Digital elevation data were used from the Shuttle Radar Topography Mission (SRTM), providing information at a resolution of $90 \mathrm{~m}$, based on the February 2000 mission (Farr et al., 2007). A number of additional cartographic information, such as administrative boundaries, was also used.

From all three databases we extracted hydrometeorological disasters. Since the disaster type and natural processes are not exactly the same in all databases, we evaluated an appropriate common basis of categories and defined them as follows:

- cold spells;

- droughts;

- precipitation, including heavy precipitation, snowfall and hail;

- floods;

- landslides, including shallow landslides, debris flows and rockfall;

To maintain the consistency over four decades from 1971 to 2009, the analysis of trends in disaster occurrence across time and space was based on the DesInventar database. DesInventar data were integrated into a geographic information system (ArcGIS, Environmental Systems Research Institute - ESRI) per disaster category, referenced to the respective administrative spatial unit (regiones, provincias and distritos). The disasters were analyzed per category, year, decade and spatial unit. The data for which the exact location of the event was not available have been excluded from the analysis.

Furthermore, it should be emphasized that disaster databases such as DesInventar and SINPAD do not consider whether a reported disaster resulted from a climatic extreme event as defined in statistical terms or not. Hence, a reported event may result from an extreme or non-extreme climatic event, where extreme is often defined as the 90th, 95th or 99th percentile of a statistical distribution (Beniston et al., 2007; IPCC, 2012; Trenberth et al., 2007). As mentioned, the criteria for inclusion of an event in DesInventar and SINPAD are not entirely clear but relate to impacts and possibly interruptions of functioning of social and economic systems.

For the analysis of damage metrics (people killed and affected over the past four decades), we used DesInventar and EM-DAT at a national scale for Peru. These two disaster databases have a different scope and documentation system, where EM-DAT records many fewer events according to the more rigid criteria given above. DesInventar, on the

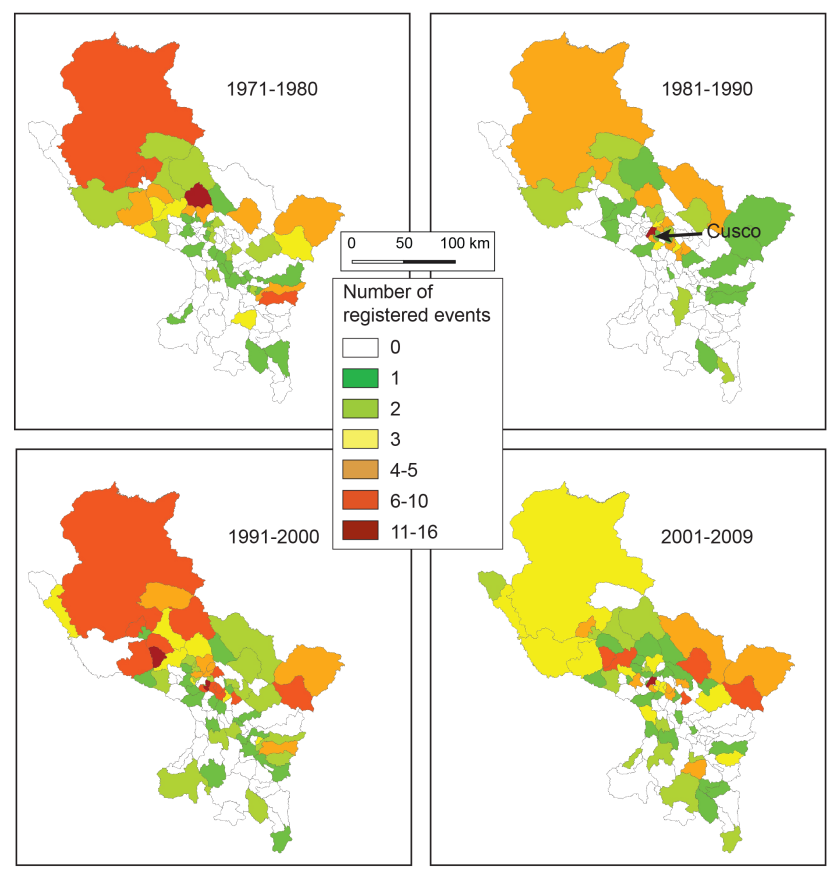

Figure 2. Spatiotemporal trends of disaster occurrence in the region of Cusco at the level of distritos over the period 1971 to 2009 (note that the last observation period only includes 9 years).

other hand, does not provide damage metrics for each event recorded.

For a third comparative analysis, focusing on a smaller spatial and temporal scale, we examined the 2010 heavyrainfall and flood disasters in Cusco, using SINPAD and DesInventar data. We also looked at rainfall data to assess how exceptional the 2010 floods were in terms of long-term climatology. Climatic data for the regiones of Cusco and Apurímac were derived from a data portal developed in the framework of the Peruvian-Swiss Programme on Climate Change Adaptation (PACC), based on operational and historical data series of more than 100 stations of the Peruvian Meteorological and Hydrological Service (SENAMHI) (Schwarb et al., 2011). This data portal facilitates the quality control of the meteorological data series and also allows the calculation of daily and monthly precipitation fields. We used the long and homogenous data series of the station Granja Kayra, near the city of Cusco $\left(13.56^{\circ} \mathrm{S}, 71.88^{\circ} \mathrm{W}\right.$, $3219 \mathrm{~m}$ a.s.l.; data record back to 1965$)$ and the hourly values of Cusco airport $\left(13.54^{\circ} \mathrm{S}, 71.94^{\circ} \mathrm{W}, 3249 \mathrm{~m}\right.$ a.s.l.).

\section{Results}

\subsection{Decadal-scale changes in disaster occurrence in Cusco and Apurímac}

For the region Cusco, the analysis at the level of distritos based on DesInventar reveals no clear pattern of change over 


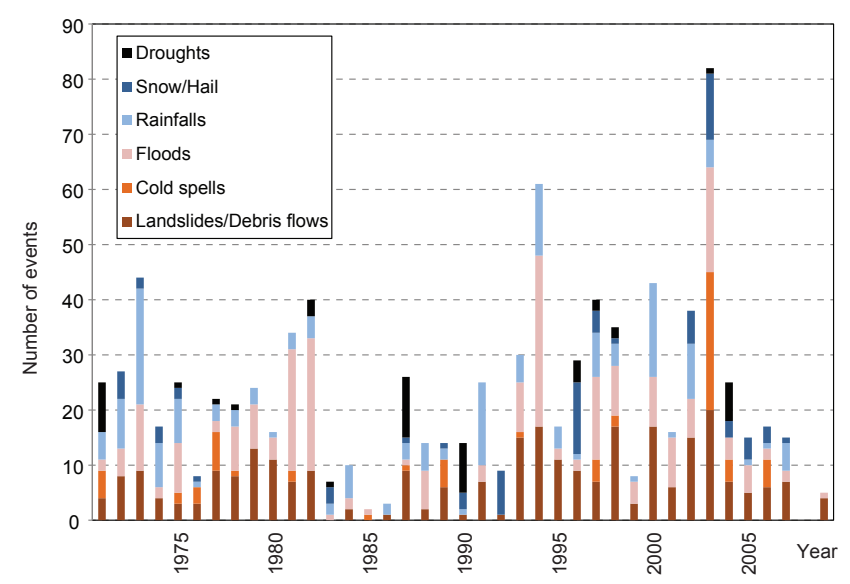

Figure 3. Number of climatic disasters in the region of Cusco and distribution according to type of event (1971-2009).

four decades (Fig. 2). For the region Cusco, the analysis at the level of distritos based on DesInventar reveals no clear pattern of change over four decades (Fig. 2), even if a low number of the events in the 1980s and a higher one during the 1990s can be noticed. As far as the spatial event distribution is concerned, distritos located to the northwest, to the northeast and around the urban centre of Cusco show the highest number of events.

This fluctuation in the frequency of events can also be seen in the representation of the annual occurrence across the whole region of Cusco (Fig. 3). Peak occurrence of events is documented in individual years, such as 1994 and 2003. During the bulk of the time period the number of events varies between about 10 and 40 per year. After the numerous events occurred in 2003 ( 82 events), the number of events decreased substantially. There is not any clear pattern visible as regards the different processes and hazard categories over time, either.

For the region Apurímac the picture is somewhat different: during the 1970s and 1980s the frequency of recorded disasters was low, and only a limited number of distritos have documented events (Fig. 4). In the 1990s the number of total events was clearly higher, and new distritos report disasters. During the first decade of the 21st century again a higher frequency of events was observed, along with a higher number of distritos being affected by disasters. The most affected distritos include Abancay (capital of Apurímac), Andahuaylas and Carhuasi, which have the highest population density (Fig. 1).

Figure 5 furthermore indicates that the higher number of events registered in the 2000s is primarily related to the first 5 years of the 21 st century, starting in 2000 and peaking in 2001. The reason for the high number of events in 2001 is predominantly heavy precipitation, with documented impacts in the form of rainfalls, floods and landslides/debris flows (Fig. 5). After this period the number of events per year

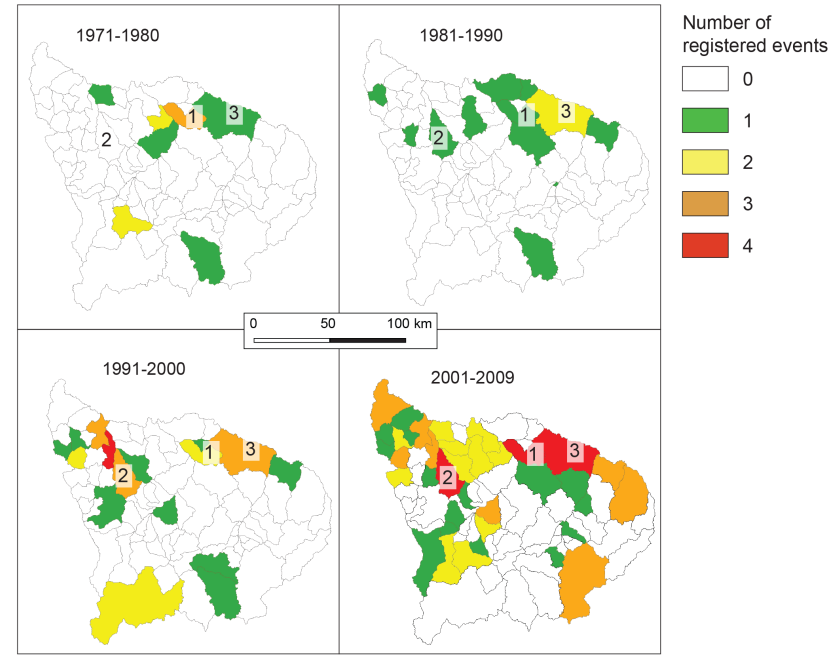

Figure 4. Spatiotemporal trends of disaster occurrence in the region of Apurímac at the level of distritos over the time period 1971 to 2009. The inset numbers indicate the most affected distritos: (1) Abancay, (2) Andahuaylas, (3) Carhuasi.

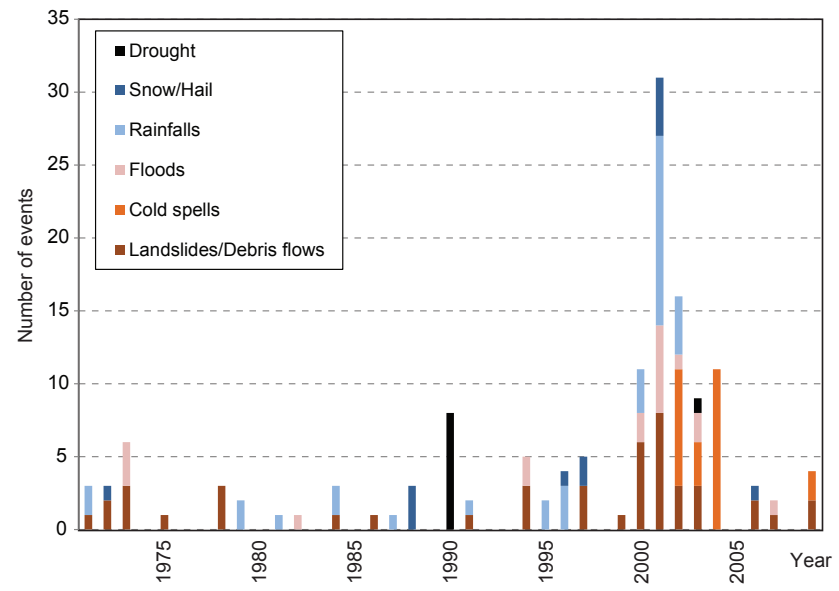

Figure 5. Number of climatic disasters in the region of Apurímac and distribution according to type of event (1971-2009).

drops again to levels observed during the last decades of the 20th century. With respect to individual disaster categories, the analysis shows that cold spells only started to occur in the 2000s, although in reality this may be an effect of missing documentation prior to the 2000s. Droughts are very rare, except for a cluster of events in 1990. Overall, it is difficult to draw any clear conclusion about trends.

\subsection{Decadal, national-scale comparative disaster loss analysis}

For 1970-2010, the national-scale comparative analysis for Peru reveals that the number of events reported by DesInventar is roughly 2 orders of magnitude larger than in EMDAT (cf. Table 1). While the number of events in DesInven- 
Table 1. A comparison of metrics of weather- and climate-related disasters in Peru in the EM-DAT and DesInventar databases. The percentages refer to the reference state of the first decade (1970s). Information on total population is derived from census from individual years (1972, 1981, 1993, 2007). Sources: CRED (2013), DesInventar (2013) and Peruvian National Institute of Statistics and Informatics (INEI).

\begin{tabular}{|c|c|c|c|c|c|c|c|c|c|}
\hline \multicolumn{10}{|c|}{ EM-DAT } \\
\hline & $\begin{array}{l}\text { No. of } \\
\text { events }\end{array}$ & $\begin{array}{r}\text { People } \\
\text { killed }\end{array}$ & $\begin{array}{l}\text { People } \\
\text { affected }\end{array}$ & $\begin{array}{r}\text { Total } \\
\text { population }\end{array}$ & $\begin{array}{r}\% \text { No. of } \\
\text { events }\end{array}$ & $\begin{array}{r}\% \text { People } \\
\text { killed }\end{array}$ & $\begin{array}{l}\% \text { People } \\
\text { affected }\end{array}$ & $\begin{array}{r}\text { Disaster } \\
\text { mortality ratio }\end{array}$ & $\begin{array}{r}\text { Ratio of affected } \\
\text { population }\end{array}$ \\
\hline 1971-1980 & 7 & 1683 & 366440 & 14121564 & 100.0 & 100.0 & 100.0 & $1.19 \times 10^{-4}$ & 0.026 \\
\hline 1981-1990 & 23 & 2038 & 1068495 & 17762231 & 328.6 & 121.1 & 291.6 & $1.15 \times 10^{-4}$ & 0.060 \\
\hline 1991-2000 & 19 & 1281 & 4758467 & 22639443 & 271.4 & 76.1 & 1298.6 & $5.7 \times 10^{-5}$ & 0.210 \\
\hline 2001-2010 & 32 & 1810 & 6034115 & 28220764 & 457.1 & 107.5 & 1646.7 & $6.4 \times 10^{-5}$ & 0.214 \\
\hline \multicolumn{10}{|c|}{ DesInventar } \\
\hline & $\begin{array}{l}\text { No. of } \\
\text { events }\end{array}$ & $\begin{array}{r}\text { People } \\
\text { killed }\end{array}$ & $\begin{array}{l}\text { People } \\
\text { affected }\end{array}$ & $\begin{array}{r}\text { Total } \\
\text { population }\end{array}$ & $\begin{array}{r}\% \text { No. of } \\
\text { events }\end{array}$ & $\begin{array}{r}\% \text { People } \\
\text { killed }\end{array}$ & $\begin{array}{l}\% \text { People } \\
\text { affected }\end{array}$ & $\begin{array}{r}\text { Disaster } \\
\text { mortality ratio }\end{array}$ & $\begin{array}{r}\text { Ratio of affected } \\
\text { population }\end{array}$ \\
\hline 1971-1980 & 2187 & 1646 & 109027 & 14121564 & 100.0 & 100.0 & 100.0 & $1.17 \times 10^{-4}$ & 0.008 \\
\hline 1981-1990 & 2740 & 1661 & 349688 & 17762231 & 125.3 & 100.9 & 320.7 & $9.4 \times 10^{-5}$ & 0.020 \\
\hline 1991-2000 & 3711 & 1437 & 641807 & 22639443 & 169.7 & 87.3 & 588.7 & $6.3 \times 10^{-5}$ & 0.028 \\
\hline 2001-2010 & 2493 & 1084 & 796616 & 28220764 & 114.0 & 65.9 & 730.7 & $3.8 \times 10^{-5}$ & 0.028 \\
\hline
\end{tabular}

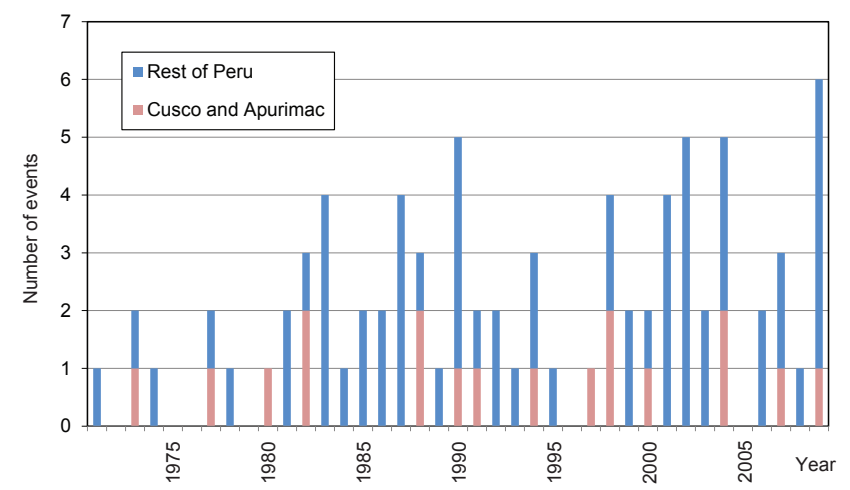

Figure 6. Number of climatic disasters in Peru from 1971 to 2009 , based on EM-DAT. Events reported for Cusco and Apurímac are highlighted.

tar reaches a peak in the 1990s, EM-DAT reports the highest number in the first decade of the 21 st century. In both databases, a low number of events is reported for the 1970s, but a clear trend in the number of reported disasters is hardly visible. If we increase the temporal resolution of the analysis and look at annual disaster reports in EM-DAT, we can recognize the year-to-year fluctuation of disasters, albeit without any strong trend (Fig. 6). Also, Fig. 6 indicates that EM-DAT is not feasible for subnational-scale analysis, due to the limited number of events reported (see highlighted Cusco and Apurímac).

The analysis of EM-DAT reveals significantly higher numbers of people affected, as compared to DesInventar. This is striking given the very large difference in reported events of the two databases. Reasons could be the different, and partly independent, sources the two databases are using, or aggregation effects due to the difference of reported events.

As regards trends over the four decades, there is a relatively good correspondence between the two databases for the number of people killed and affected (Table 1). The number of people killed fluctuates in EM-DAT within a range of $\pm 20 \%$ from 1971 to 2010, while DesInventar shows a reduction of $35 \%$ from the 1970s to the most recent decade. For people affected, DesInventar and EM-DAT document a 7-fold and an almost 20-fold increase, respectively, over the four decades. Hence, while the number of people killed by weather- and climate-related extreme events remained approximately stable during the past 40 years in Peru, an enormous increase of people affected is reported. The absolute numbers between EM-DAT and DesInventar differ by about 1 order of magnitude for people affected since the 1990s, but the strong increasing trend is likely a robust result.

\subsection{Local-scale single extreme event: the 2010 floods in Cusco}

The region of Cusco was hit by intense rainfall between January and March 2010. The highest rainfall intensities were recorded in late January 2010. The most affected provincias include Anta, Calca, Quispicanchi, Urubamba and La Convención (see Fig. 1). Negative impacts were mainly due to floods, landslides or debris flows, triggered by the intense and long-duration precipitation. Floods were particularly devastating around 24/25 January 2010 along the Huatanay River downstream from the city of Cusco, and in the Urubamba Valley along the Vilcanota River (Fig. 7). International media reports focused on the large-scale evacuation of tourists 


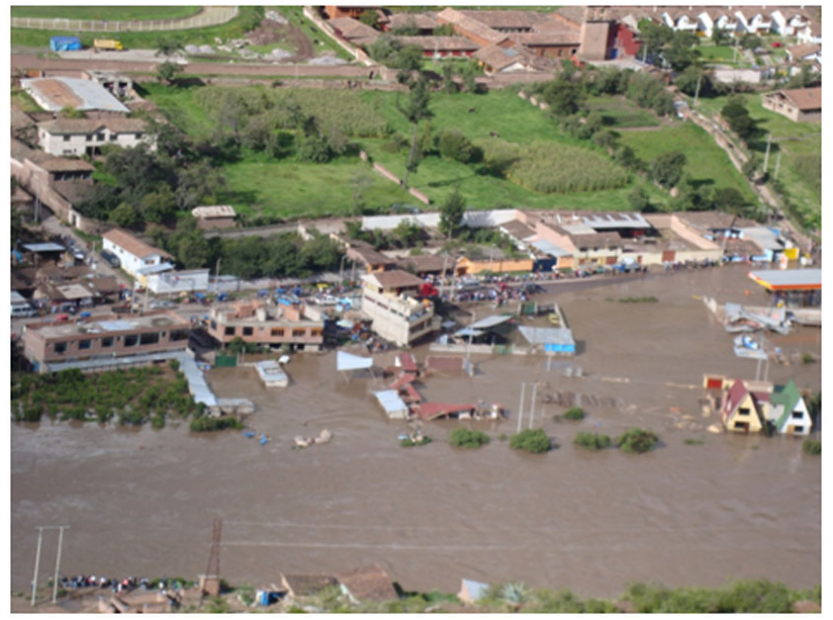

Figure 7. January 2010 floods with parts of the city of Urubamba (provincia of Urubamba, region of Cusco; cf. Fig. 1) inundated by the Vilcanota River (photo: Municipalidad de Urubamba).

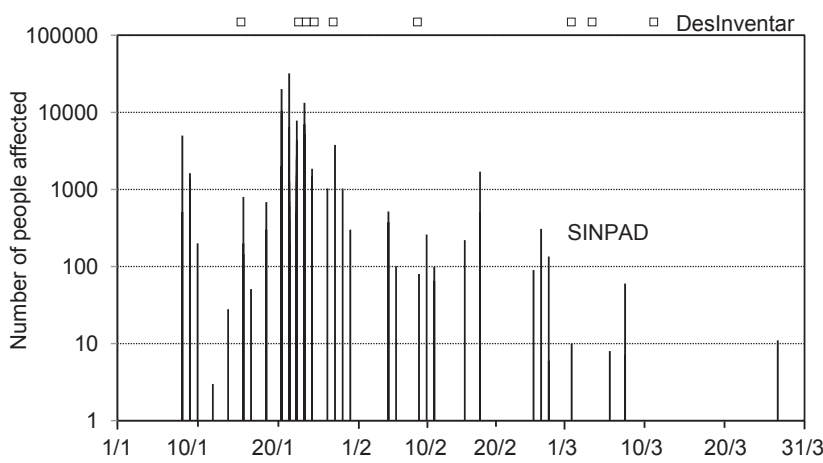

Figure 8. Comparison between individual disaster events for the January to March 2010 period as registered by DesInventar and SINPAD for the region of Cusco. The number of people affected ( $y$ axis) only refers to SINPAD records; DesInventar just indicates the date of occurrence at the top of the graph.

locked in the Machu Picchu area, due to transportation lines cut by floods.

Estimates of damage to people, infrastructure and services vary considerably. Analysis of data available through the INDECI disaster database SINPAD indicates a total number of about 191000 people affected, 206 injured and 17 killed, between January and March 2010. Another source of INDECI, however, states a total of about 63000 people affected, 382 injured and 26 killed in different provincias of Cusco (INDECI, 2012). The large difference in terms of people affected could be due to cumulative counting for each event record in the first case (SINPAD) and an overview number in the second case.

Even larger differences in disaster metrics are revealed by a comparison of SINPAD and DesInventar databases for the extended period of rainfall/flood events in the region of Cusco from January to March 2010. SINPAD provides mul- tiple and detailed records of events, while DesInventar only documents a fraction of these events, with either incomplete or lacking information about people affected (Fig. 8).

INDECI reports furthermore document that almost 5000 residential houses were destroyed, and more than 7300 were affected. Especially notable is that, in the provincias of Anta and Quispicanchi, 34 and $31 \%$ of all residential houses were destroyed, respectively. The total economic damage was estimated to be about 635 million nuevos soles (ca. USD 220 million), with an approximate shared damage of $35 \%$ on health, education and housing; $55 \%$ on infrastructure (mainly transport and communication); and $8 \%$ on tourism and agriculture (INDECI, 2012). Major indirect financial loss was caused by a breakdown of tourist influx into Cusco, due to disruption of access to Machu Picchu for several months.

To investigate whether, and to what extent, the 2010 event was extraordinary in terms of climatic record, we first have to consider that year-to-year precipitation variability in the Altiplano region of the Central Andes of Peru is high. For the station Granja Kcayra (near Cusco), the standard deviation of monthly January precipitation is $46 \mathrm{~mm}$ (mean value: $146 \mathrm{~mm}$ ), with a minimum value of $59 \mathrm{~mm}$ and a maximum value of $233 \mathrm{~mm}$, for the period 1965-2009. January 2010 precipitation amounted to a total of $269 \mathrm{~mm}$ and represents a new long-term monthly maximum. The value is 2.67 standard deviations above the long-term mean (1965-2009).

Additional insight into the extreme 2010 event can be gained from the calculation of the extreme-value statistics. Figure 9 shows the highest 1-day, 2-day and 5-day precipitation sums for all years between 1965 and 2011. The analysis shows that the 5-day precipitation sum from 22 to 26 January 2010 represents the most exceptional rainfall metric of this analysis, with a precipitation value of more than $130 \mathrm{~mm}$. The return period of such a 5-day-value, estimated based on the 47-year record, is about 200 years. Putting the 2010 rainfall and flood events in a context of climate change, the data indicate minimum changes in 1-day and 2-day maximum precipitation since 1965 and a moderate increase of 5-day maximum precipitation in the 1980 s, with a stabilization on a higher level since then (Fig. 10).

Furthermore, hourly data of the Cusco airport indicate that, during the abovementioned 5-day stretch, precipitation was characterized by quite intensive short rainfalls. However, daily precipitation sums were not particularly high, which is confirmed by the 1-day and 2-day data of the Granja Kcayra station, with approximate return periods of 5 to 20 years, respectively (Fig. 9). Taking this into account, it seems that the unusual sequence of wet days is more important for flood generation in the Cusco area than a single extreme precipitation event. This may be an important piece of information when planning a flood warning system. With respect to the relation between climatic extreme events and disaster losses, it is interesting to note that the days with most people affected 


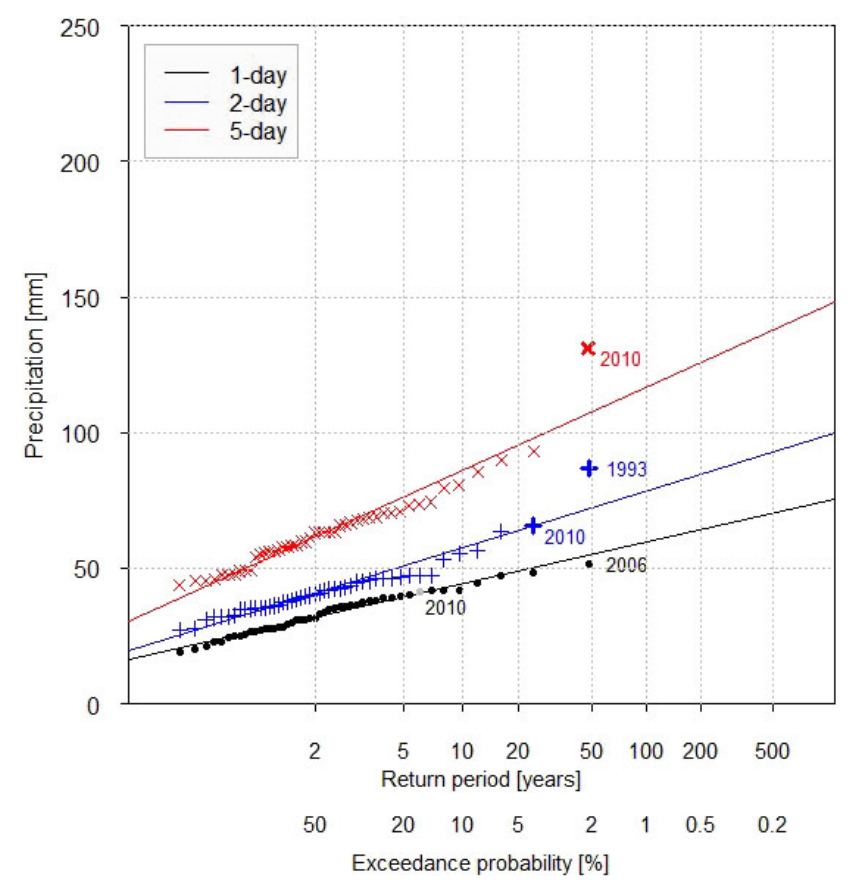

Figure 9. Extreme-value distribution of 1-day (black crosses), 2day (blue crosses) and 5-day (red dots) precipitation sums of Granja Kcayra near the city of Cusco (data from SENAMHI), arranged by their respective ranking. The reference period is 1965-2011. The $x$ axis is scaled with the Gumbel extreme-value distribution.

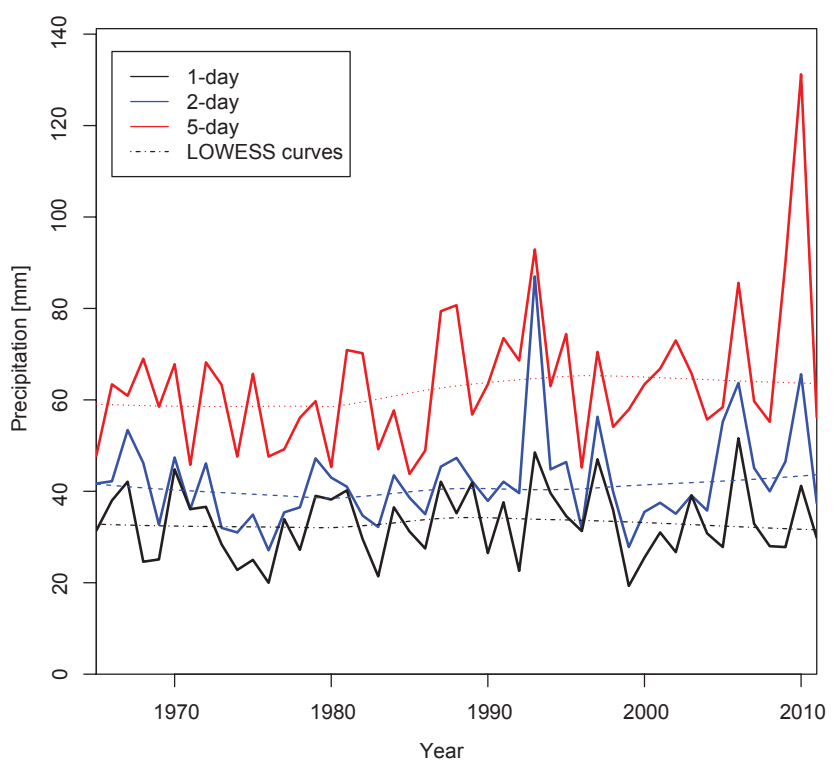

Figure 10. Analysis of 1-, 2- and 5-day maximum precipitation based on data from the local meteorological station Granja Kayra (Cusco) between 1965 and 2011. Trends are calculated using a locally weighted polynomial regression (LOWESS) and indicate minimum changes in 1-day and 2-day maximum precipitation, and a moderate increase of 5-day maximum precipitation in the 1980s with a stabilization on a higher level since then. (in SINPAD) coincides with the days of maximum precipitation (21 to 26 January, Fig. 8).

\section{Discussion and conclusions}

The criteria for inclusion of events in the disaster databases analyzed here are rather arbitrary, and often not handled in a consistent way. Recent studies in fact confirm the large differences in reporting, documentation, completeness and quality of disaster databases (UNDP, 2013). However, there is still limited understanding of the related implications when such disaster data are analyzed and conclusions drawn. Methods to circumvent or mitigate these problems have scarcely been developed. This is especially true for developing countries, where insurance penetration is low and therefore disaster databases of large re-insurance companies are of limited use.

This study intends to foster insights into limitations and potential of disaster databases and their application in a developing country context, by comparing three different databases across different spatial scales, time periods and damage metrics.

The analysis for Cusco and Apurímac, using DesInventar, does not reveal any striking pattern in disaster occurrence over the past four decades, although it does show a clearly higher number of disasters in the last decade for Apurímac and therefore also highlights region-specific trends. Apparently, restricting the analysis to event occurrence neglects the impact dimension. It has to be considered that, for instance, one large event can cause more damage than 10 smaller events together. An analysis of underlying causes of observed patterns in disaster occurrence is difficult and essentially limited by availability of required data. This limitation is also recognized at the international level, and therefore the UNFCCC calls for enhancing data and understanding of loss and damage related to climate change effects.

To adequately account for the limitations in reporting damage metrics, we analyzed the national-scale picture for Peru. We have seen that the number of people killed is approximately stable over the four decades, even though the exposed population has greatly increased. The number of affected people, however, strongly increased during the same period. Similar differential trends in these two disaster metrics have been seen in other countries, such as Colombia (Marulanda et al., 2010; UNISDR, 2013), and are generally consistent with global trends (Golnaraghi et al., 2009). However, the fact that the number of people killed remained approximately stable (or even decreased) is remarkable, given the population growth since the 1970s. The reasons for the decrease in mortality rate are not known in detail for Peru, but we may assume that improved efforts in disaster risk reduction by government and non-government institutions are at least one factor, just as suggested for the corresponding global-scale trends (Golnaraghi et al., 2009; WMO, 2013). 
For Peru, the increase of affected people can be linked to the strong increase in population, implying a growing number of exposed people. At this point, it is important to consider not only the absolute numbers of people affected but also the relation to total population dynamics. The ratio of affected population to total population is increasing in both databases - according to EM-DAT almost with a factor of 10 between the 1970s and the 2000s, whereas DesInventar indicates a factor-of-4 increase for the same period (Table 1). Furthermore, EM-DAT indicates a $\sim 10$ times higher ratio than DesInventar for the last two decades.

There are two pertinent conclusions we can draw from this analysis. First, the difference of disaster metrics and their rates depending on the database analyzed can be enormous, and consequently the interpretation and implications in terms of policies and actions could be different as well. Second, the protection of lives has been improved over time, but the vulnerability of people, as a driver of disaster damage (i.e., people affected), has likely increased. The second conclusion should be further explained here. Disaster fatalities and economic damage can be seen as a proxy for disaster risk, which is a function of the frequency and magnitude of the physical weather event, exposure and vulnerability of people or assets (Huggel et al., 2013; IPCC, 2012). Observed changes in disaster damage can be a result of a change in one or more of those variables. A detailed related analysis would, however, require a more comprehensive data set, which is generally difficult obtain. The fact that the ratio of people affected to total population is increasing over time implies that exposure is likely not the only driver, especially when considering the magnitude of increase. Frequency and magnitude of the extreme weather events, and vulnerability, remain possible drivers. Although a comprehensive study is lacking, we have no indication that extreme weather events at the national scale of Peru have significantly changed over the past decades (see also Fig. 10). Hence, vulnerability remains a likely driver of change. However, we should stress that currently available data and information are not yet sufficient to draw definite conclusions and more research is needed. Other recent studies suggest a decline in vulnerability in many world regions, including South America (Peduzzi et al., 2012). But whether the average number of people killed per million exposed, as used in their study, is an adequate proxy for vulnerability is not clear. Cutter and Finch (2008), for instance, emphasize the dynamic nature of vulnerability and have found both positive and negative trends in the USA.

The disaster damage analysis of the 2010 heavy-rainfall and flood event in Cusco again showed the large difference in records of different disaster databases. Generally, our comparative analysis indicates that ignoring such differences and shortcomings in disaster analyses over different spatial scales and time periods can result in important flaws in the conclusions on either trends or other aspects relevant for adaptation and risk reduction. The lack of standards concerning the evaluation of disaster impact (Guha-Sapir and Below, 2002) makes an analysis over larger geographic spaces a challenge. EM-DAT defines clear criteria for inclusion of events in the database and should therefore provide a higher level of consistency. However, in EM-DAT, as seen here, the great majority of small and medium natural hazard events go unnoticed. This is an important shortcoming because presumably the cumulative impact of such events is decisive for livelihood and poverty dynamics in countries like Peru (Hardoy and Pandiella, 2009; Marulanda et al., 2010).

In view of a maximum value of disaster databases for disaster risk reduction and climate adaptation efforts, we identify the following conclusions and recommendations: (i) for any analysis of disaster databases the type, method and source of documentation is crucial and should be carefully evaluated; (ii) the criteria for reporting disaster events are important but often not sufficiently clear, and they are often established in an arbitrary way; (iii) the sources of information and documentation should be strengthened, in particular with regards to damage and impact data; (iv) coordination between different databases would be desirable to avoid generation and communication of different results and conclusions.

Acknowledgements. This study was conducted within the Peruvian-Swiss Programme on Climate Change Adaptation (PACC), funded by the Swiss Agency for Development and Cooperation (SDC). We appreciate collaboration with several colleagues from the PACC, including Helvetas Swiss Intercooperation, as well as fruitful discussions with Yamina Silva, Pierluigi Calanca, Walter Silverio, Christine Jurt, Massimiliano Zappa, Norina Andres, Nadine Hilker and Thomas Konzelmann. We also acknowledge support of Daniela Lorenzi for one figure. Collaboration with, and data from, SENAMHI Peru is greatly appreciated. We also acknowledge input in the context of AndesPlus/Adaptation to the Impact of Rapid Glacier Retreat in the Tropical Andes Project (PRAA), funded by the Swiss Federal Office for the Environment, the World Bank and the Andean Community of Nations. Finally, we thank Olga Petrucci and the anonymous reviewers for helpful and detailed comments that improved the manuscript.

Edited by: M.-C. Llasat

Reviewed by: O. Petrucci and two anonymous referees

\section{References}

Adger, W. N., Huq, S., Brown, K., Conway, D., and Hulme, M.: Adaptation to climate change in the developing world, Prog. Develop. Stud., 3, 179-195, 2003.

Barredo, J. I.: Normalised flood losses in Europe: 1970-2006, Nat. Hazards Earth Syst. Sci., 9, 97-104, doi:10.5194/nhess-9-972009, 2009.

Barredo, J. I.: No upward trend in normalised windstorm losses in Europe: 1970-2008, Nat. Hazards Earth Syst. Sci., 10, 97-104, doi:10.5194/nhess-10-97-2010, 2010. 
Barthel, F. and Neumayer, E.: A trend analysis of normalized insured damage from natural disasters, Climatic Change, 113, 215237, doi:10.1007/s10584-011-0331-2, 2012.

Beniston, M., Stephenson, D. B., Christensen, O. B., Ferro, C. A. T., Frei, C., Goyette, S., Halsnaes, K., Holt, T., Jylhä, K., and Koffi, B.: Future extreme events in European climate: an exploration of regional climate model projections, Climatic Change, 81, 71-95, 2007.

Bouwer, L. M.: Have Disaster Losses Increased Due to Anthropogenic Climate Change?, Bull. Am. Meteorol. Soc., 92, 39-46, doi:10.1175/2010BAMS3092.1, 2011.

CRED: EM-DAT The International Disaster Database, Centre for Research on the Epidemiology of Disasters - CRED, available at: http://www.emdat.be, Université Catholique de Louvain, Brussels (Belgium), 2013.

Cutter, S. L. and Finch, C.: Temporal and spatial changes in social vulnerability to natural hazards, Proc. Natl. Acad. Sci., 105, 2301-2306, 2008.

Cutter, S. L., Barnes, L., Berry, M., Burton, C., Evans, E., Tate, E., and Webb, J.: A place-based model for understanding community resilience to natural disasters, Global Environ. Change, 18, 598-606, 2008.

DesInventar: DesInventar - Inventory system of the effects of disasters, Corporación OSSA, Cali, Colombia, available at: http: //desinventar.org, last access: 25 November 2013.

Farr, T., Rosen, P., Caro, E., Crippen, R., Duren, R., Hensley, S., Kobrick, M., Paller, M., Rodriguez, E., Roth, L., Seal, D., Shaffer, S., Shimada, J., Umland, J., Werner, M., Oskin, M., Burbank, D., and Alsdorf, D.: The Shuttle Radar Topography Mission, Rev. Geophys., 45, RG2004, doi:10.1029/2005RG000183, 2007.

Füssel, H. M.: How inequitable is the global distribution of responsibility, capability, and vulnerability to climate change: A comprehensive indicator-based assessment, Global Environ. Change, 20, 597-611, doi:10.1016/j.gloenvcha.2010.07.009, 2010.

Gall, M., Borden, K. A., and Cutter, S. L.: When Do Losses Count?, Bull. Am. Meteorol. Soc., 90, 799-809, doi:10.1175/2008BAMS2721.1, 2009.

Golnaraghi, M., Douris, J., and Migraine, J. B.: Saving lives through early warning systems and emergency preparedness, in: Risk Wise, 137-141, Tudor Rose, Leiceister, England, 2009.

Guha-Sapir, D. and Below, R.: The quality and accuracy of disaster data a comparative analyses of three global data sets, Technical document. The ProVention Consortium and the Disaster Management Facility, The World Bank, WHO Centre for Research on the Epidemiology of Disasters, University of Louvain School of Medicine, 2002.

Hardoy, J. and Pandiella, G.: Urban poverty and vulnerability to climate change in Latin America, Environ. Urban., 21, 203-224, doi:10.1177/0956247809103019, 2009.

Huggel, C., Stone, D., Auffhammer, M., and Hansen, G.: Loss and damage attribution, Nat. Clim. Change, 3, 694-696, doi:10.1038/nclimate1961, 2013.

INDECI: Evaluación del impacto socio-económico de la temporada de lluvias 2010 en la Región Cusco, Instituto Nacional de Defensa Civil del Perú, Lima, Perú, 2012.

INDECI: SINPAD - Sistema de Información Nacional para la Respuesta y Rehabilitación, Insituto Nacional de Defensa Civil, Lima, Perú, available at: http://sinpad.indeci.gob.pe, last access: 4 November 2013.
IPCC: Managing the Risks of Extreme Events and Disasters to Advance Climate Change Adaptation. A Special Report of Working Groups I and II of the Intergovernmental Panel on Climate Change, edited by: Field, C. B., Barros, V., Stocker, T. F., Qin, D., Dokken, D. J., Ebi, K. L., Mastrandrea, M. D., Mach, K. J., Plattner, G.-K., Allen, S. K., Tignor, M., and Midgley, P. M., Cambridge University Press, Cambridge, UK, and New York, NY, USA, 2012.

ISDR: Global assessment report on disaster risk reduction. Risk and poverty in a changing climate, United Nations, Geneva, Switzerland, 2009.

Kron, W., Steuer, M., Löw, P., and Wirtz, A.: How to deal properly with a natural catastrophe database - analysis of flood losses, Nat. Hazards Earth Syst. Sci., 12, 535-550, doi:10.5194/nhess12-535-2012, 2012.

Marulanda, M. C., Cardona, O. D., and Barbat, A. H.: Revealing the socioeconomic impact of small disasters in Colombia using the DesInventar database, Disasters, 34, 552-570, doi:10.1111/j.1467-7717.2009.01143.x, 2010.

Munich Re: NatCatSERVICE, available at: http://www.munichre. com/natcatservice (last access: 22 December 2014), 2014.

Neumayer, E. and Barthel, F.: Normalizing economic loss from natural disasters: a global analysis, Global Environ. Change, 21(, 13-24, 2011.

Peduzzi, P. and Herold, H. D. C.: Mapping Disastrous Natural Hazards Using Global Datasets, Nat. Hazards, 35, 265-289, doi:10.1007/s11069-004-5703-8, 2005.

Peduzzi, P., Dao, H., Herold, C., and Mouton, F.: Assessing global exposure and vulnerability towards natural hazards: the Disaster Risk Index, Nat. Hazards Earth Syst. Sci., 9, 1149-1159, doi:10.5194/nhess-9-1149-2009, 2009.

Peduzzi, P., Chatenoux, B., Dao, H., De Bono, A., Herold, C., Kossin, J., Mouton, F., and Nordbeck, O.: Global trends in tropical cyclone risk, Nat. Clim. Change, 2, 289-294, doi:10.1038/nclimate1410, 2012.

Pielke Jr., R. A., Gratz, J., Landsea, C. W., Collins, D., Saunders, M. A., and Musulin, R.: Normalized hurricane damage in the United States: 1900-2005, Nat. Hazards Rev., 9, 29-42, 2008.

Schmidt, S., Kemfert, C., and Höppe, P.: The impact of socioeconomics and climate change on tropical cyclone losses in the USA, Reg. Environ. Change, 10, 13-26, 2010.

Schwarb, M., Acuña, D., Konzelmann, T., Rohrer, M., Salzmann, N., Lopez, B. S., and Silvestre, E.: A data portal for regional climatic trend analysis in a Peruvian High Andes region, Adv. Sci. Res., 6, 219-226, 2011.

Swiss Re: Sigma: Insurance research, available at http://www. swissre.com/sigma/ (last access: 22 December 2014), 2014.

Tapia, M.: Los sistemas de producción agrícola campesina en los andes del Perú, La Sostenibilidad de Los Sistemas de Produccion Campesina en Los Andes, 131, 1997.

Trenberth, K. E., Jones, P. D., Ambenje, P., Bojariu, R., Easterling, D., Klein Tank, A., Parker, D., Rahimzadeh, F., Renwick, J. A., Rusticucci, M., Soden, B., and Zhai, P.: Observations: Surface and Atmospheric Climate Change, in Climate Change 2007: The Physical Science Basis. Contribution of Working Group I to the Fourth Assessment Report of the Intergovernmental Panel on Climate Change, edited by: Solomon, S., Qin, D., Manning, M., Chen, Z., Marquis, M., Averyt, K. B., Tignor, M., and Miller, 
H. L., 235-336, Cambridge University Press, Cambridge, United Kingdom and New York, NY, USA, 2007.

UNDP: A comparative review of country-level and regional disaster loss and damage databases, Bureau for Crisis Prevention and Recovery, United Nations Development Programme, New York, USA, 2013.

UNISDR: La ruralidad, la fragilidad urbana y el fenómeno La Niña en Colombia, 1970-2011. Background Paper prepared for the Global Assessment Report on Disaster Risk Reduction 2013, Corporación OSSO, Cali, Colombia, Geneva, Switzerland, 2013.
Wisner, B., Blaikie, P. M., Cannon, T., and Davis, I.: At risk: natural hazards, people's vulnerability and disasters, Routledge, 2004.

WMO: WMO disaster risk reduction programme, World Meteorological Organization, available at: http://www.wmo.int/pages/ prog/drr/ (last access: 25 November 2013), 2013. 